\title{
ANCIENT ROMAN FORTRESS SOSTRA AS A CULTURAL AND HISTORICAL TOURIST RESOURCE
}

\author{
Plamen Lakov ${ }^{1}$, Ivanka Shopova ${ }^{2}$ \\ University of Agribusiness and Rural development (Bulgaria)
}

\begin{abstract}
The paper is part of a research series for ancient Roman sites in Northern Bulgaria which aim to present the possibilities of creating a specialized form of cultural and historical product that ensures sustainable utilization of the Bulgarian tangible heritage. A study of the Roman fortress Sostra, located on the Via Traiani road as a cultural and historical tourist resource was conducted. The castellum is characterized as an object of cultural heritage in the region of Troyan Municipality in Bulgaria. The methodology applied in assessing the potential of the Ancient Roman fortress Sostra is primarily designed for historical and cultural sites. An evaluation was made under the following criteria: potential for development, degree of impact / interaction, degree of modification with relevant indicators. Also an expedition-field method for terrain research was applied. Summaries and conclusions were made in order to highlight the possibility of forming a tourist product of cultural and cognitive tourism.

KEYWORDS: tourist resource, cultural tourism, tourism policy, regional development.
\end{abstract}

JEL CODES: L83, R 58.

DOI:

\section{Introduction}

Bulgaria is a country with a unique cultural and historical heritage. Historically, the country existed among the most ancient civilizations and cultures such as the Thracian, Roman and Old Bulgarian. Almost 40,000 registered sites dated back to different historical eras are a proof for the richness of Bulgarian cultural heritage. Seven sites have the status of immovable cultural values of global significance and more than 10 000 have national heritage importance. Bulgaria ranks third in Europe after Greece and Italy for the number of its valuable archaeological and cultural monuments (National Strategy for the Sustainable Development of Tourism in Bulgaria 2014-2030). This makes cultural tourism a promising sector for developing and allows Bulgaria to become a regional leader in Central and South-eastern Europe. European and global trends in tourism development also support this assertion.

A survey, requested by the European Travel Commission (Ministry of tourism), which has studied preferences and reasons for travel of tourists, visiting Europe, shows that relatively high proportions of tourists who go on a holiday in European destination are the most likely to say that cultural and sports tourism are a concomitant goal to travel (39\%). In turn $45 \%$ of Russian tourists visiting Europe combine the holiday with cultural activities. Tourists from Canada (60\%), Japan and Korea (34\%) have the same motivation to travel.

1 Plamen Lakov - professor, University of Agribusiness and Rural development, Faculty of Economics and Management, Department of Regional development and tourism

Scientific interests: tourism, regional development

E-mail:plakov@uard.bg

2 Ivanka Shopova - assit. professor, University of Agribusiness and Rural development, Faculty of Economics and Management, Department of Regional development and tourism

Scientific interests: tourism, regional development

E-mail: ishopova@uard.bg 
In 2018 Bulgaria was visited by a total of 9273345 foreign citizens (Ministry of tourism, statistics). The share of European tourists is $61.4 \%$, Russian $-5.6 \%$, Ukrainian $-4 \%$ and Canadian $-2 \%$. In this regard, more than $70 \%$ of the tourist flow to Bulgaria for 2018 has a potential for diversification through cultural tourism product. However, the holiday tourism retains its leading position for the same period $-62.6 \%$ of all tourist visits. Analysis of the Bulgarian tourism market shows that the share of cultural tourism is slightly above $10 \%$. It must be emphasized that the potential of Bulgaria to develop cultural tourism and the demand for such a product from outbound tourism market do not match the actual supply.

The contrast to Bulgaria's positioning worldwide is even more pronounced. By the Natural and Cultural Resources subindex which is a part of the Travel \& Tourism Competitiveness Index (TTCI) 2015 framework, Bulgaria is rated 1.96. By this subindex ranking the country attains the $54^{\text {th }}$ position out of 141 countries included in the survey as in the Balkans only Montenegro is after Bulgaria (Levkov, 2017). The TTCI benchmarks the T\&T competitiveness of 141 economies. It comprises four subindexes, 14 pillars and 90 individual indicators, distributed among the different pillars. The Survey data is derived from responses to the World Economic Forum's Executive Opinion Survey and range in value from 1 to 7. Each of the pillars has been calculated as an unweighted average of the individual component variables (Travel \& Tourism Competitiveness Index, 2015).

Reasons for poor performance of Bulgaria at cultural tourism market are complex and they are listed in founding documents for tourism development such as "Strategy for Sustainable Development of Tourism in Bulgaria 2014-2030" (Ministry of tourism, Bulgaria). Therefore, the topic will not be discussed in detail. For the purposes of this study will be pointed out that one of the main reasons for this is the insufficient readiness of objects of tangible cultural heritage from potential tourist resource to become a basis for setting up competitive tourism product.

\section{Material and methods}

The study is part of a survey of ancient sites on the territory of Pleven and the region. As a territory bordering Romania, sites located in the region can become the basis for development both for an internal and international tourism. This will contribute to the balanced economic development of the region and the alternative employment of labor resources. In this connection, ancient sites are considered as a resource with a potential for tourism development.

The study aims to present the possibility of creating a regional tourist product based on the ancient Roman castellum Sostra. In the specialized literature the tourist product is defined as a concept that contains a substantial material substance and at the same time it is also a set of services. The tourist product also includes resources and attractions, conditions and infrastructure, activities, imaginative presentations and values. Together they have to meet the needs of a particular group of users. It is clear that services are the basis of the tourist product while it has also a material basis, such as tourist resources (Banabakova, et. al., 2017). They are one of the factors motivating potential tourists to choose a destination. In this case it is the cultural heritage in the district of Lovech, namely the ancient Roman castellum Sostra.

The following tasks will help to achieve the above goal:

1. A characteristic of the site is presented.

2. An evaluation of the potential of cultural and historical tourism resources of the ancient Roman castellum Sostra according to specific criteria is made.

In assessing the potential of ancient Roman castellum Sostra, a methodology has been applied that reviews the site as an anthropogenic tourist resource. According to the Methods for evaluation of cultural and historical tourist resources and their potential, the following three criteria for evaluating are used:

1. Capacity (potential, ability) Development $(\mathrm{CD})$ - consistent with the factors and conditions for development of the resource.

2. Degree of impact / influence - the level of attractiveness is estimated. 
3. Degree of modification (resulting from the tourism) - evaluation of utility / value / significance of the tourist attraction.

For the assessment are used:

- method of point rating - a certain number of points is awarded by the selected characteristics of cultural and historical resources, specific indicators to measure them and aggregate subjective opinions;

- the sum of the awarded points from the total rating of the given object;

- selected characteristics and corresponding indicators have different weight in the assessment, which is defined in points (1 to 100);

- the maximum number of points for a certain object is 100 and it is formed as a sum of the points for each of the selected and evaluated characteristics and indicators;

- a scoring matrix is developed which takes into account the main characteristics of cultural and historical tourist resource Roman castellum Sostra, used in the measurement and evaluation along with their inherent indicators - significance and weight (Table 1).

The following research methods are used in the study:

- expedition field method - field work, the method of observation and interview method;

- mapping method;

- expert evaluation method as a part of heuristic evaluation.

The authors have complied with the idiographic approach that highlights the unique features and competitive characteristics of the site.

\section{General characteristics of Roman roadside station and castellum Sostra}

In the first third of the first century $\mathrm{AD}$, the territory where the Roman road station and castellum Sostra are situated was part of the Roman Empire as the province of Moesia. This is a consequence of long military campaigns completed during the time of Emperor Tiberius, reigning from $14 \mathrm{AD}$ to $37 \mathrm{AD}$. Romans built many roads that serve the army, administration and trade within the Empire and beyond (Figure 1). Trajan time is part of the road system of the Roman Empire. Its construction began during the reign of Tiberius (14-37) but was finished and actively used during the Emperor Trajan (98-117) when he transformed Dacia (Dacia Trajana) into Roman province. After Philipopolis Via Traiani was incorporated into another great Roman road - starting from Singidunum (today the Serbian capital Belgrade) continuing to Serdica (mod. Sofia), Philippopolis (mod. Plovdiv) and Adrianopolis (mod. Edirne in Turkish Thrace). At certain distances along the main roads the Romans built roadside stations and ancient castrum (fortified military camp) that served as a protected place for accommodation, storage facilities for food, weapons, horses changing point, and administrative records. According to a Roman road map (illustrated itinerarium), known as Tabula Peutingeriana, the way stations via Trajan's road on Bulgarian territory were nine: Oescus 14 Roman miles (village of Gigen, Pleven district), Ad Putea 7 (village of Riben, Pleven dist.), Storgisia 11 (Pleven), Doriones 10 (village of Slatina, Lovech district), Melta 13 (Lovech), Sostra 10 (village of Lomets, Troyan district), Ad Radice (village of Beli Osum), Monte Naemno (Beklemeto), Sub Radice (village of Hristo Danovo, Plovdiv district).

The Roman roadside station and castellum Sostra is situated on a territory which in the Pre-Roman period $(1 \mathrm{BC})$ is associated with the lands inhabited by the Thracian tribe of Krobyzoi. Sostra is the sixth station, serving Via Trayana. "Sostra" from ancient Greek means belt, bandaging, barrier). The castellum is located in the Osam river valley. It is part of the Troyan Fore-Balkan. It consists of low hills with an east-west stretch, cut from the rivers, in this case from the valley of the Osam River through the village of Lomets.

On the cartosheme, it is well seen (Figure 1) that Sostra is situated directly on the Roman road and it is the last one before it enters the central mountain massif.

Today, apart from the section studied at Sostra, sections of it are preserved in the Central Stara Planina (Figure 2). 


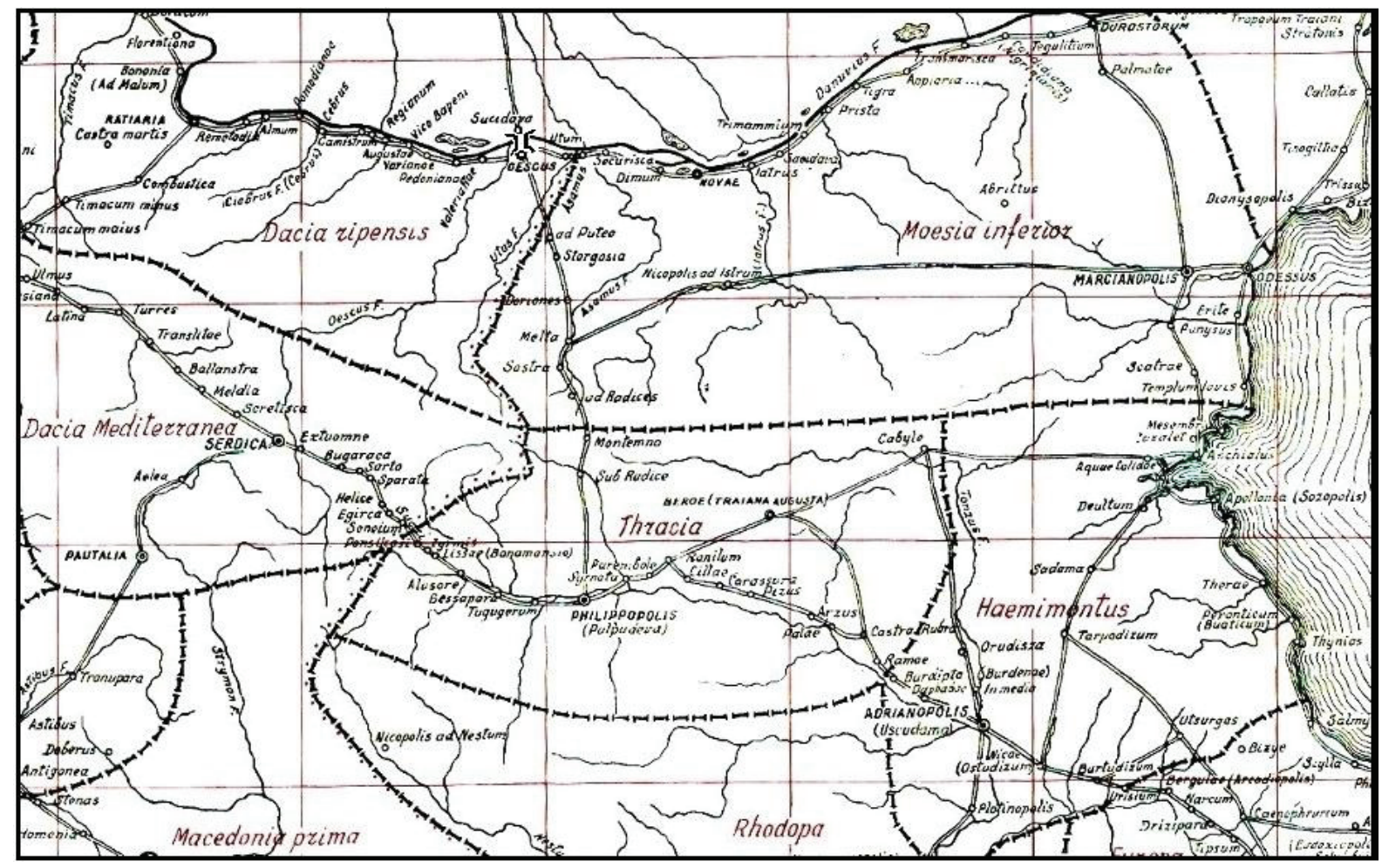

Figure 1. Schematic map of Roman roads in Bulgaria in IV -VI centuries

Source: V. Tapkova-Zaimova, V. Velkov

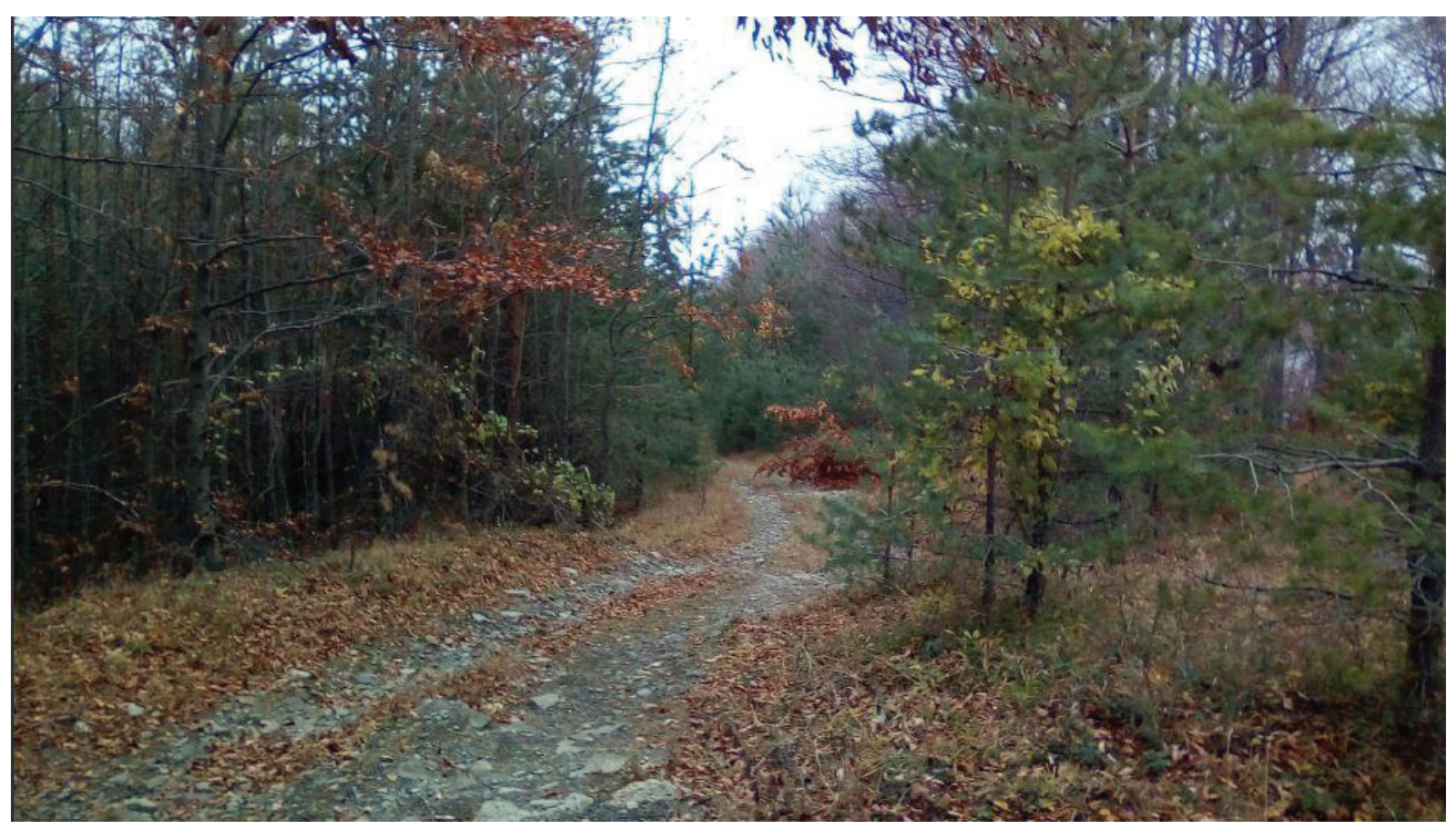

Figure 2. A section of Via Traiani in the Balkan Mountains

Source: authors' archive 
The castellum Sostra is located $150 \mathrm{~km}$ east of Sofia $150 \mathrm{~km}$, near the village of Lomets and about $16 \mathrm{~km}$ north of the town of Troy and $28 \mathrm{~km}$ south of Lovech. The location of the fortress is strategic, because the access to the south to Troyan was controlled, and the roadway was in the immediate vicinity of it. The eastern (main) gate of the fortress was turned in the direction of the "Kalugerskoto" locality, from where it was the only passage to the upper course of the Osam River.

Sostra was twice destroyed by the Goths in the middle of the $3^{\text {rd }}$ and the second half of the $4^{\text {th }}$ century, but it was recovered after these invasions. Initial archaeological studies showed that Sostra included settlements, necropolises, a roadside station and a strong fortress (castellum). The entire valley where the fortress is situated covers an approximate area of $4 \mathrm{~km}^{2}$. Sostra was founded in the middle of the $2^{\text {nd }}$ century and it existed for more than 300 years. Four construction periods have been established. Sostra fort was built around 145 AD at the order of Roman Emperor Antoninus Pius during his fourth consulate (Hristov, 2011). Around 147 AD the cohors II Mattiacorum was stationed in Sostra and the construction of the the castellum began. It was so called cohors milliaria, i.e. around 1000 soldiers (milliaria). There are evidences of the presence at a later stage of Cohors I Cisipadensium in Sostra, First Spanish Gordian cohort (cohors I Hispanorum Gordiana), and part of the I Aurelian Cohort.

In the late period of its existence (IV-V centuries) barbaric mercenaries played the role of militia. With the invasions of Goths and Huns, the castle of Sostra lost its military significance and it became a civilian settlement. Sostra was completely destroyed by the Huns at the end of the $5^{\text {th }}$ century. In the $19^{\text {th }}$ century a small road inn called "Lomeshki Hancheta" was built.

Sostra is a base camp. According to Hristov (2011) the Latin term "castellum" can be used for a fortified military camp. The term is a diminutive form of "castra". This term designated the bearings of auxiliary parts, as is the case with Sostra. It was found that the plan of this castellum is similar to a rhombus whose larger diagonal is oriented to the northwest - southeast (figure 3). The fortified territory covers an area of approximately $1.5 \mathrm{ha}(125 \mathrm{~m}$ west-east x $121.5 \mathrm{~m}$, north-south). Exact measurements allow the calculation of the standard sized cohors quingenaria units. In its present form, Sostra presented a plan of a fortified fortress, the achievement of which occurred at the end of the $3^{\text {rd }}$ century and the beginning of the $4^{\text {th }}$ century. The fortress was built in strict compliance with the natural features of the plain around the Azamus River (today Osam River). At the center of the castellum was the principia or the military headquarters (figures 4 and 5). Infront of the principia passed the main stree Via Principalis. Against it at right angles to Via Principalis passed the second main street Via Pretoria. Part of the fortification of Sostra castellum was implemented by towers at the gates and corners of the fortification. There are two types of towers - rectangular, flanking the gates in the middle of the curtain wall and rounded - at the corners (Figures 6 and 7). All towers in the castellum were covered with tegulae and imbrices. 


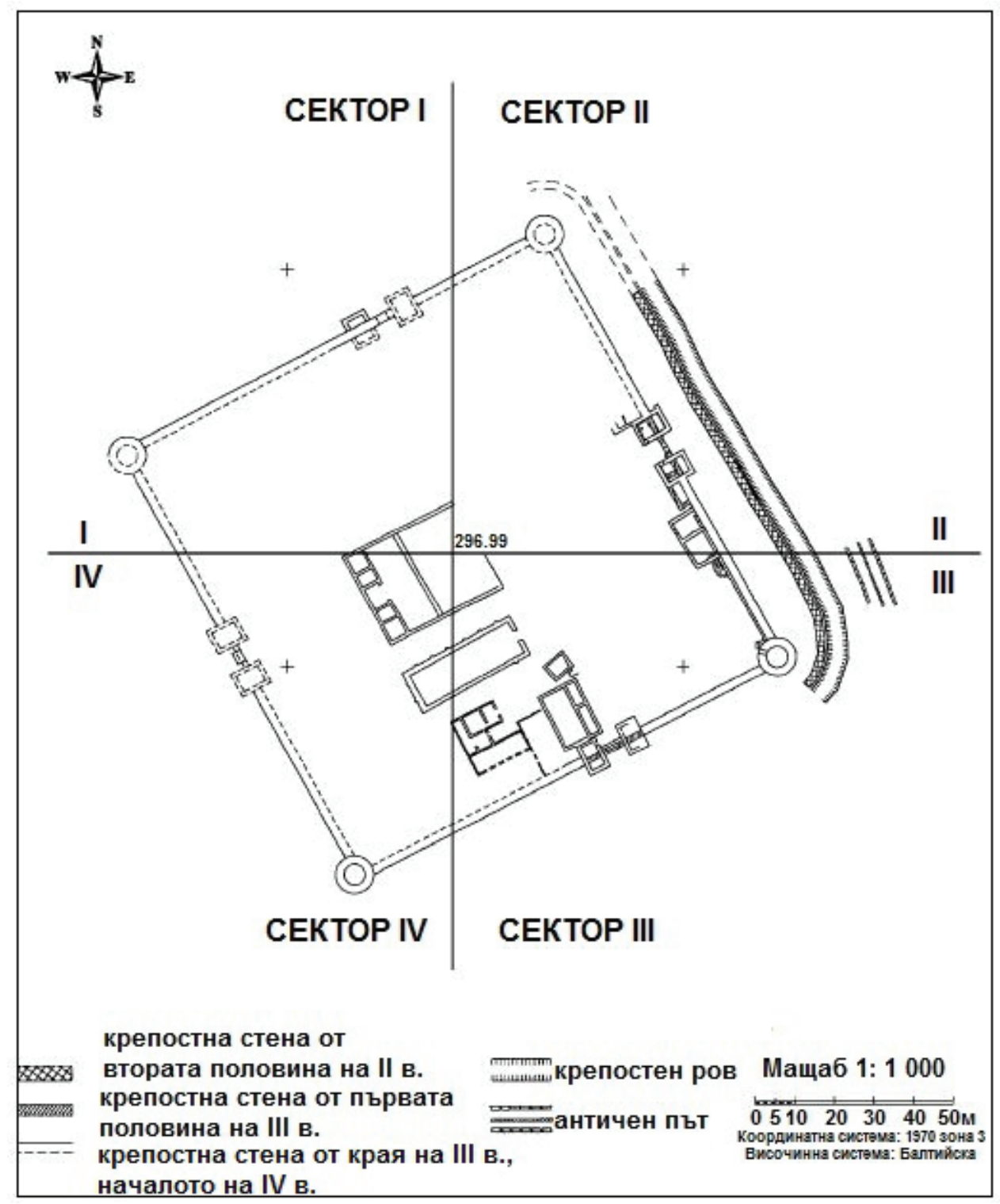

Figure 3. Plan of castellum Sostra

Source: Hristov, 2011

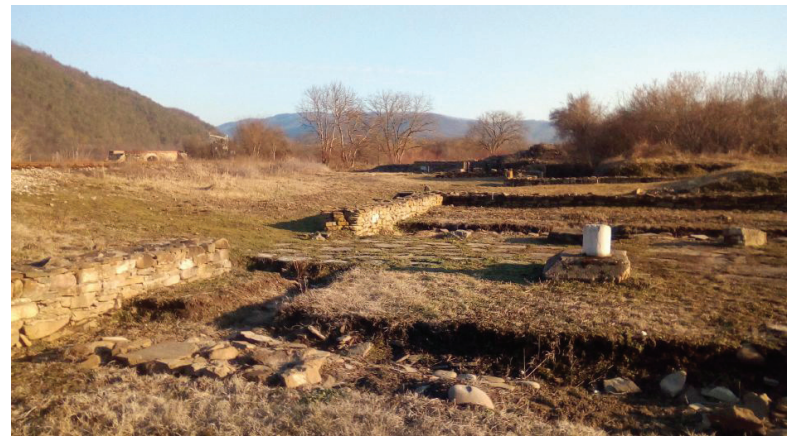

Figure 4. Via Principalis

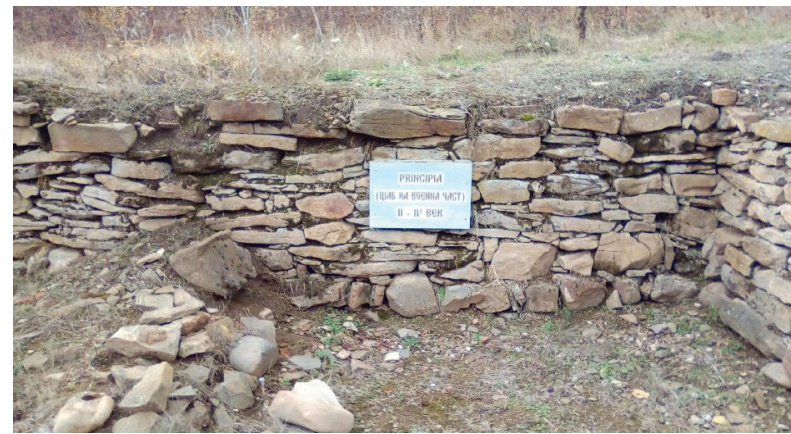

Figure 5. Military headquarters

Source: authors' archive 

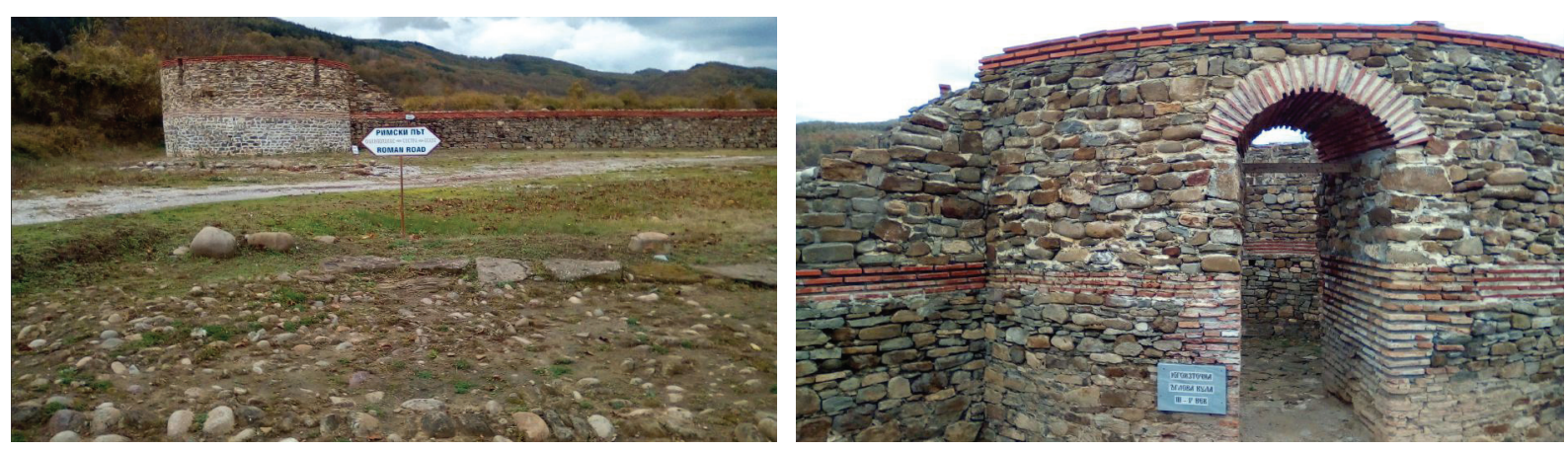

Figures 6 and 7. Southeastern round tower and part of the Roman road

Source: authors' archive

The rectangular towers of Sostra are located in the middle of the fortress walls near the gates in order to secure and protect them. Their external dimensions, with a few exceptions, are the same $8 / 6.50 \mathrm{~m}$. They are $1 / 3$ out of the line of the fortress wall (Hristov, 2011), (Figures 8, 9 and 10).
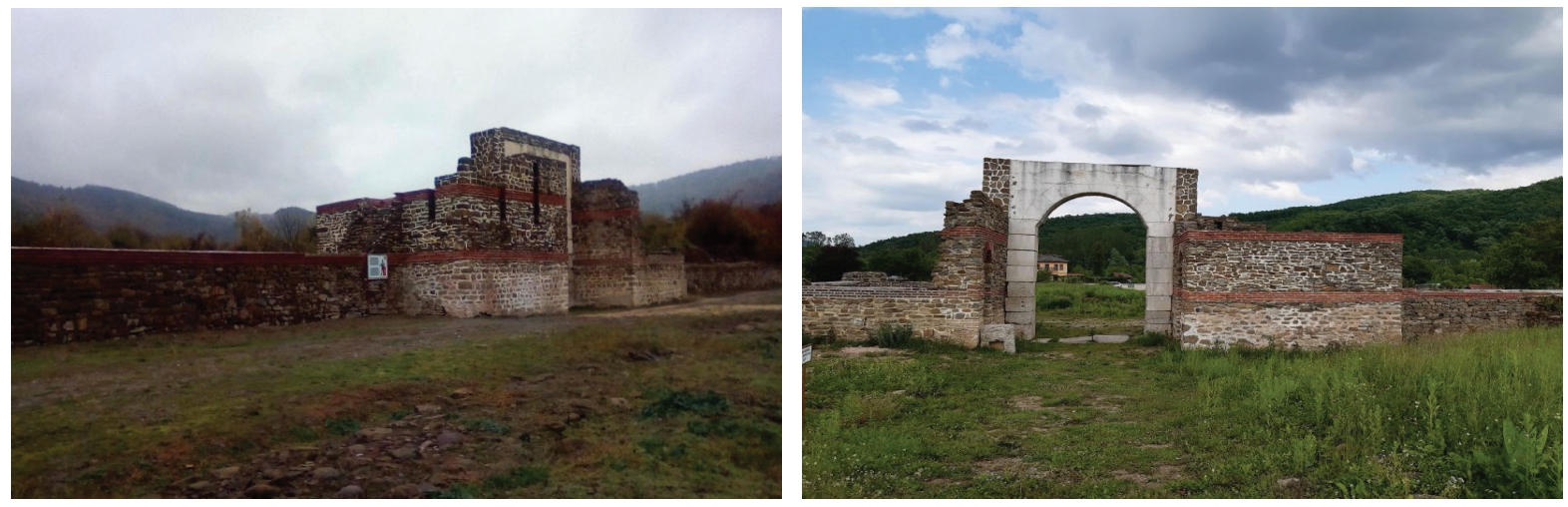

Figures 8 and 9. Eastern fortress wall with main gate and rectangular towers

Source: authors' archive

The Roman road passes immediately before the eastern fortress. A great length of the road is revealed, divided into two lanes with an axial line, a banquet and a width of $7 \mathrm{~m}$ (Figure 11).

The organizational archaeological research of the Roman complex has been done by Dr. Georgi Kitov, Totyu Totevski, Assoc. Prof. Sergei Torbatov (National Archaeological Museum of Bulgarian Academy of Science) and prof. dr. Ivan Hristov (National Historical Museum). The first organized archaeological researches in the region of Sostra were held in 1979 under the guidance of Professor Georgi Kitov. Since 2002 there are regular exploratory and restoration activities under the guidance of prof. dr. Ivan Hristov from the National Museum of History and with the cooperation of the Municipality of Troyan and the Museum of Crafts. Major sections of the military camp, buildings from the civilian settlement, early Christian basilica, ceramic furnace, sanctuary of Thracian god rider, roadside station etc. were studied. During the excavations, silver coins, clay pots and jewels were found. Part of the findings are exhibited at the Museum of Crafts in the town of Troyan. 


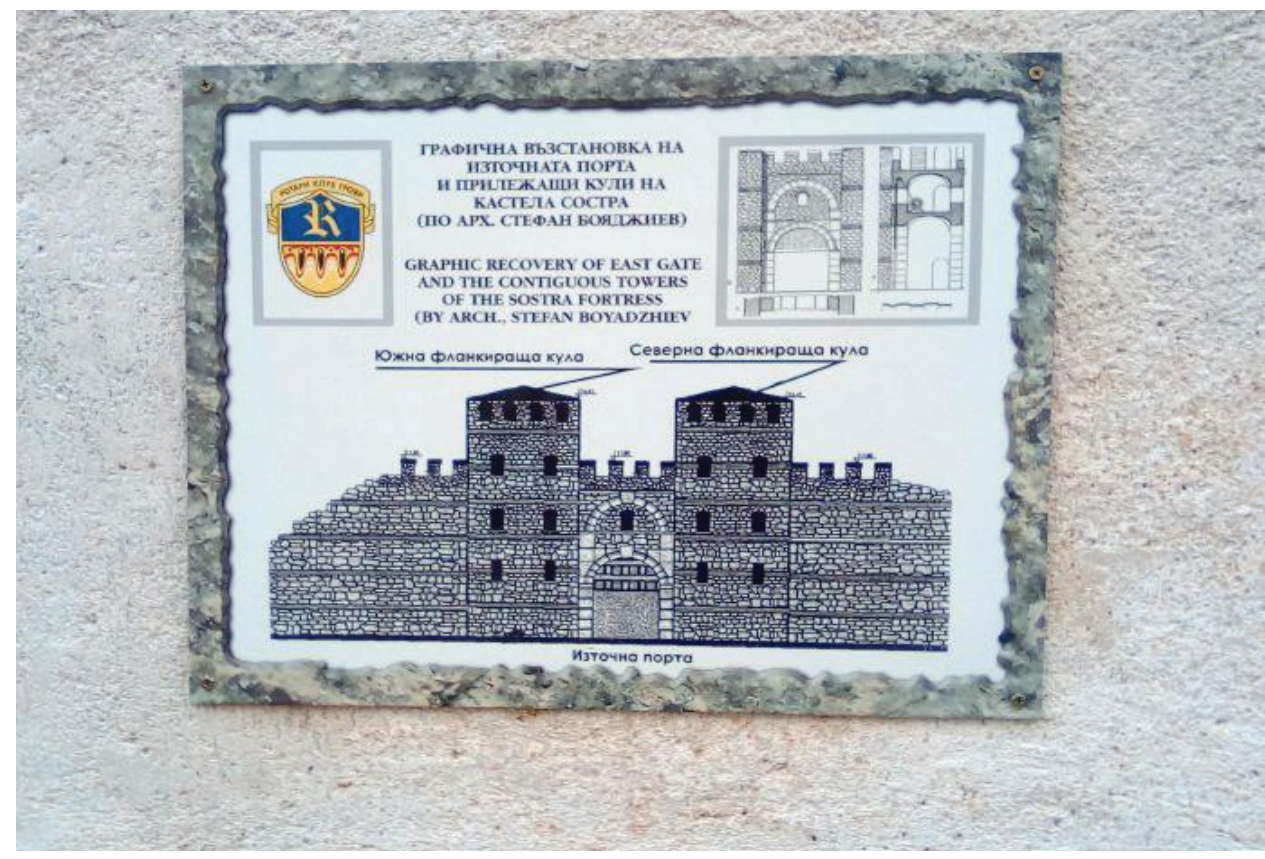

Figure 10. Reconstruction of the east gate of the castellum Sostra Source: authors' archive

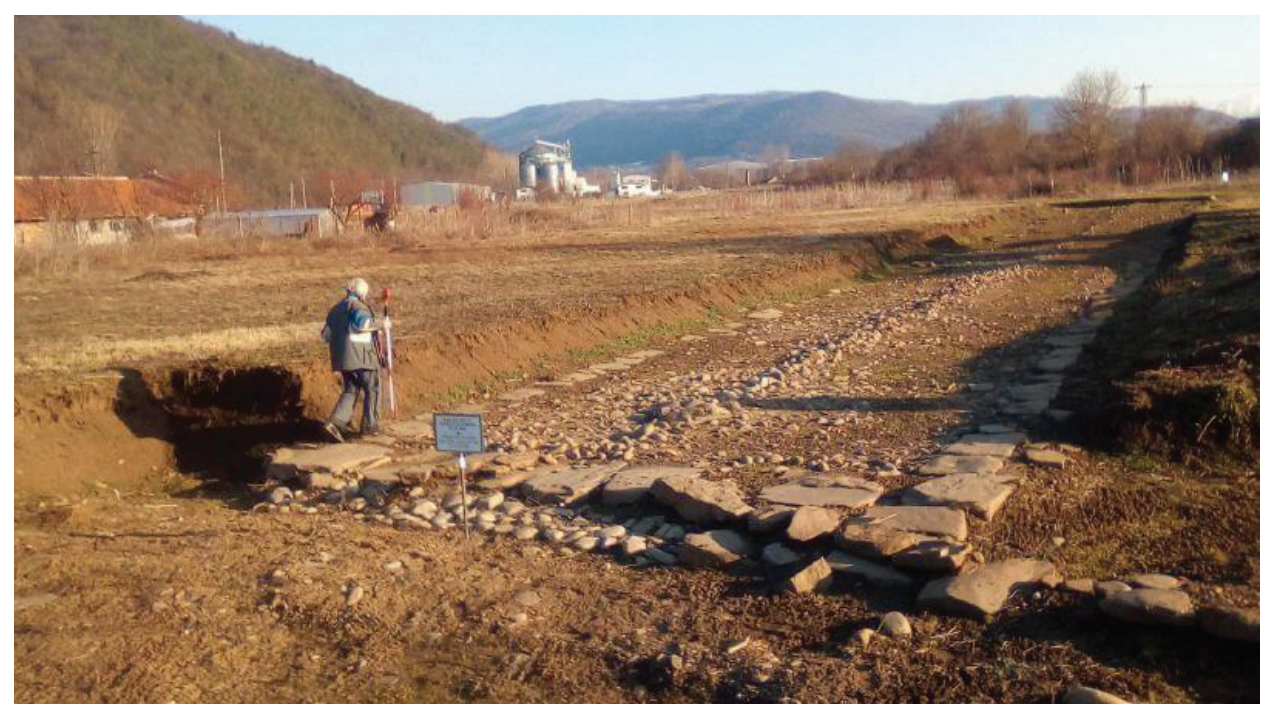

Figure 11. Part of Via Traiani right in front of the Sostra castellum

Source: authors' archive

4. Evaluation of potential of the Ancient Roman fortress Sostra as cultural and historical tourist resource

Complex evaluation of cultural and historical tourist resources of Ancient Roman fortress Sostra is 57 points from maximum 100 possible points (Table 1). 
Table 1. Main characteristics and indicators for assessment of the historical and cultural tourism resources of the Ancient Roman fortress Sostra

\begin{tabular}{|c|c|c|c|c|c|c|}
\hline \multirow[b]{2}{*}{ No. } & \multirow[b]{2}{*}{$\begin{array}{l}\text { Defining characteristics } \\
\text { (associated with the } \\
\text { main criteria) }\end{array}$} & \multirow[b]{2}{*}{ Indicators and metrics } & \multicolumn{4}{|c|}{ Weighting (number of points) } \\
\hline & & & Max & Max & $\begin{array}{l}\text { For the } \\
\text { object }\end{array}$ & $\begin{array}{l}\text { Max } \\
\text { for the } \\
\text { object }\end{array}$ \\
\hline 1 & $\begin{array}{l}\text { Attractiveness } \\
\text { (Criterion 2) }\end{array}$ & $\begin{array}{l}\text { 1. Prominence / popularity } \\
\text { 2. Combined with beautiful and diverse } \\
\text { landscape } \\
\text { 3. Authenticity / preservation } \\
\text { 4. Uniqueness } \\
\text { 5. Beauty / exotic } \\
\text { 6. Cognitive / scientific value } \\
\end{array}$ & $\begin{array}{l}1.5 \\
2.3 \\
\\
3.4 \\
4.5 \\
5.4 \\
6.4 \\
\end{array}$ & 25 & $\begin{array}{l}1-2 \\
2-3 \\
3-4 \\
4-3 \\
5-3 \\
6-3\end{array}$ & 18 \\
\hline 2 & $\begin{array}{l}\text { Importance } \\
\text { (Criterion 2) }\end{array}$ & $\begin{array}{l}\text { 1. Worldwide (incl. The UNESCO) } \\
\text { 2. National (incl. } 100 \text { National Tourist } \\
\text { Sites of Bulgaria) } \\
\text { 3. Local } \\
\text { 4. Ensemble } \\
\text { 5. Monuments for reference }\end{array}$ & $\begin{array}{l}1.8 \\
2.5 \\
3.2 \\
4.2 \\
5.1\end{array}$ & 18 & $\begin{array}{l}1-0 \\
2-0 \\
3-2 \\
4-1 \\
5-1\end{array}$ & 4 \\
\hline 3 & $\begin{array}{l}\text { Accessibility } \\
\text { (Criterion 1) }\end{array}$ & $\begin{array}{l}\text { 1. All vehicles / buses (incl. oversized) } \\
\text { 2. Only by car } \\
\text { 3. Only off-road vehicles } \\
\text { 4. Accessible by foot }\end{array}$ & $\begin{array}{l}1.5 \\
2.3 \\
3.2 \\
4.1 \\
\end{array}$ & 11 & $\begin{array}{l}1-5 \\
2-3 \\
3-2 \\
4-1\end{array}$ & 11 \\
\hline 4 & $\begin{array}{|ll|}\text { Capacities / carrying } \\
\text { capacity } & \\
\text { (Criterion 2) } & \\
\end{array}$ & $\begin{array}{l}\text { 1. Carrying capacity (number of visitors } \\
\text { weekly, daily, per } 1 \text { hour) } \\
\text { 2. Facility carrying capacity } \\
\text { 3. Ecosystems load level } \\
\text { 4. Possible maximum number of visitors } \\
\text { /per } 1 \mathrm{~m}^{2} / \\
\text { 5. Ratio number of visitors - the number } \\
\text { of beds }\end{array}$ & $\begin{array}{l}1.3 \\
2.3 \\
3.3 \\
4.2 \\
5.2\end{array}$ & 13 & $\begin{array}{l}1-3 \\
2-3 \\
3-2 \\
4-1 \\
5-\text { no data } \\
\text { available }\end{array}$ & 9 \\
\hline 5 & $\begin{array}{l}\text { Utilization for the needs } \\
\text { of tourism } \\
\text { (Criterion 3) }\end{array}$ & $\begin{array}{l}\text { 1. Safety in use } \\
\text { 2. Degree of exploration } \\
\text { 3. Guaranteed period of operation } \\
\text { 4. Capital intensity }\end{array}$ & $\begin{array}{l}1.4 \\
2.2 \\
3.4 \\
4.3 \\
\end{array}$ & 13 & $\begin{array}{l}1-2 \\
2-1 \\
3-3 \\
4-2 \\
\end{array}$ & 8 \\
\hline 6 & $\begin{array}{l}\text { Readiness to accept and } \\
\text { service } \\
\text { tourists } \\
\text { (Criterion 3) }\end{array}$ & $\begin{array}{l}\text { 1. Availability of tourist infrastructure } \\
\text { and superstructure } \\
\text { 2. Level of staffing provision } \\
\text { 3. Presence / absence of guide services } \\
\text { 4. Degree of suitability for formation of } \\
\text { tourist products }\end{array}$ & $\begin{array}{l}1.7 \\
2.5 \\
3.3 \\
4.5\end{array}$ & 20 & $\begin{array}{l}1-4 \\
2-0 \\
3-0 \\
4-3\end{array}$ & 7 \\
\hline & & TOTAL NUMBER OF POINTS FROM T & HE MA & XIMUN & (100) & 57 \\
\hline
\end{tabular}

\section{Results and Discussion}

By the "attractiveness" criterion 2, the site has been rated 18 by a maximum of 25 points. This is mainly due to the authenticity of the site, the beautiful landscape and its cognitive and scientific value. Under these criteria insufficient popularity is one of the weaknesses of the site. The "accessibility" criterion has the maximum rating points. The site has a built-in transport infrastructure. It is available for all types of vehicles as well as on foot. 
Directly next to the main road there is a parking lot and signs are placed. A macadam leads to the fortress. A serious disadvantage is the safety of the site. Through it passes unsafe for pedestrians' railway line (Figure 12).

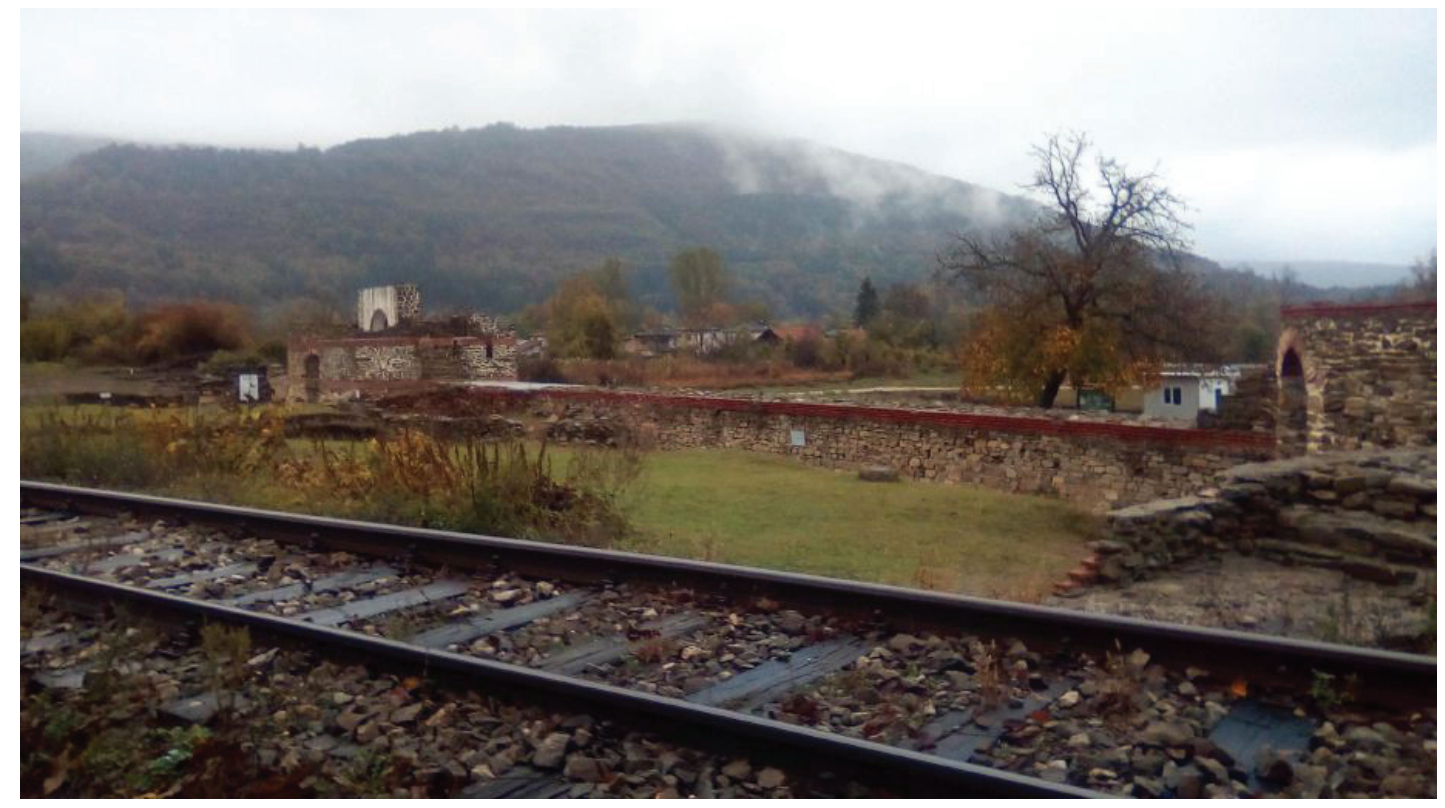

Figure 12. Railway line Lovech - Troyan passes via castellum Sostra

Source: authors' archive

The indicator "Utilization for the needs of tourism" (criterion 3) is estimated at $69 \%$ of the maximum possible. This is due to the degree of exploration of the fortress, the restoration and conservation of the sites, as well as the exploitation potential that exists during the year. Lack of visitor data is an obstacle to fully assessing the subject under this indicator. This criterion has the potential for a higher grade.

For the good assessment of these two indicators is also contributed by the realized project of National Historical Museum and Municipality of Troyan related to exploration, restoration and conservation of Sostra.

Criteria "Importance" (criterion 2) has the lowest rating. In general, the site has local significance and it is not part of an ensemble. It is also not popular and interesting for tourists outside the region. Potential tourists can be attracted by incorporating the site as a cultural and historical tourist resource into a comprehensive regional tourist product.

According to the "Readiness to accept and service tourists" criterion the Roman roadside station and castellum Sostra received only $35 \%$ of the maximum points. The site has partly developed tourist infrastructure, but the lack of superstructure and trained staff reduces the its tourist value. At present, the site does not offer tour guide services. The visit mode is free. There is a lack of a permanent staff which reduces the satisfaction and aesthetic perception of the site by tourists and the opportunities for ongoing maintenance.

\section{Conclusions}

The Roman fortress of Sostra has the potential to form a tourist product of cultural and cognitive tourism. It is an archaeological site partly prepared for visiting by tourists. A competitive advantage is the location of the site next to the main road Lovech - Troyan - Troyan Pass. At the same time, the lack of developed thematic cultural and tourist product remains the object isolated and unknown to potential tourists.

There is, however, good practice in local government to turn Sostra into an attractive tourist destination. First of all, the municipality has acquired the caste as a property. Together with the state and public-private partnership, the municipality has invested funds in exploration, conservation and restoration of the site. In the planning documents of the Troyan municipality for the period 2014-2020, the sustainable development of tourism is considered 
as one of the five priorities for development of the region (Municipal Development Plan of Troyan for the period 2014-2020). The authors of this paper believe that good cooperation has been achieved between the Municipality and the National history museum, as a result of which in the beginning of 2019 the investment project: "Archaeological complex Sostra - restoration, exhibition and socialization of Roman castle and Roman roadside station $-1^{\text {st }}$ stage" was presented. The investment project was prepared with funds from the municipal budget. It envisages preservation, exposure and socialization of Sostra. Main activities are: recovering Sostra's vision through conservation methods and technologies, as well as readable exposure solutions; providing access for people with mobility disabilities, alleyways and artistic lighting; creating an attractive part, safe passage of visitors through the railway line; Last but not least, build a visitor center as well as a dining and accommodation facility (Minicipality of Troyan. News section). During the implementation of the project, the weaknesses in the above assessment will be removed and Sostra to a large extent will be completed as a tourist site. The question remains about the implementation of the project commitments, as well as how Sostra and other ancient sites in the region to be combined in a common thematic, regional tourist product. They are territorially located on three districts and two tourist regions. On the other hand, they are at a different stage of development as objects of cultural tourism. This makes it very difficult to coordinate efforts to achieve progress in this direction. One of the reasons for this is the weaknesses of the current tourist zoning of the country (Levkov, Lakov, 2018). More than 5 years the destination management system is not working properly which could be one of the possible solutions to the discussed problem.

\section{References}

Banabakova, V., Velikov, V., Levkov, K., Lakov, P. (2017). Tourism markets. Pleven Chista priroda.

Hristov, I. (2011). Sostra Roman Castellum, Road-side Station and Settlements on the Road Oescus (Ulpia Oescus) Philippopolis. Construction periods in building a fortified camp and its development from II to V century. National Historical Museum, Vol. 23, p. 60-81. Sofia.

Ivanov, R. (1999). The Lower Danube defense system between Dorticum and Durostorum from August to Maurikius. Sofia.

Lakov, P. Naydenov, V., Shopova, I. (2017). Analysis of the cultural and historical tourist resource of the Roman legionary fortress and Early Byzantine town of Novae. New Knowledge Journal of science, p. 159-170. ISSN 2367-4598 (Online); ISSN 1314-5703 (Print).

Lakov, P., Levkov, K., Shopova, I. (2018). The potential of the late-antique and early Byzantine fortress Storgozia as a cultural and historical tourist resource. Collection of papers from the scientific conference "Regional Economy and Sustainable Development", Vol. 1. p. 587-599. Economic University of Varna: Science and economics. ISBN 978-954-21-0956-3.

Lakov, P., Naydenov, V., Shopova, I. (2017). Cultural Tourism: Opportunities For Regional Tourism Product Development, The Case Of Roman Militum Castra "Dimum". International Balkan and Near Eastern Social Sciences Congress. Series Kırklareli / Turkey, September 23-24, p. 745-756. ISBN 978-605-67815-0-6.

Lakov, P., Naydenov, V., Shopova, I. (2017). The Roman Colonia Ulpia Oescensium and opportunities for developing cultural tourism. International Balkan and Near Eastern Social Sciences Congress Series-Russe / BULGARIA April 8-9, p. 228-241. ISBN 978-619-203-177-0.

Levkov, K., Lakov, P. (2018). Tourism zoning of Bulgaria - state and problems. Туристическите райони на България състояние и проблеми. Collection of papers from the scientific conference "Regional Economy and Sustainable Development", Vol. 1, p. 497-506. Economic University of Varna Publisher: Science and economics. ISBN 978954-21-0956-3.

Levkov, K. (2017). Bulgaria's place in world tourism (an attempt to positioning). New Knowledge Journal of Science, Vol. 6, No. 1. UARD - Bulgaria: Talent. http://science.uard.bg/index.php/newknowledge/article/view/208/172. ISSN 2367-4598 (Online).

Markov, I., Apostolov, N. (2008). Tourist resources. Varna: Asparta, p. 52-69.

Mihaylov, M. (2012). Strategic approaches to development of cultural tourism. NBU.

Mitova-Dzhoneva, D. (1979). Archaeological sites in the district of Pleven. Sofia.

Tapkova-Zaimova, V., Velkov, V. (2017). Schematic map of Roman roads on the territory of Bulgaria in IV-VI c. The Roman Colonia Ulpia Oescensium and opportunities for developing cultural tourism. IBANESS, Congress SeriesRusse/BULGARIA, April 8-9, p. 232.

Methods for evaluation of cultural and historical tourist resources and their potential. IPA Cross-Border Programme CCI Number 2007CB16IPO008, Alliance for regional and civil initiatives (ARCI) -Haskovo branch. 
Ministry of tourism in Bulgaria. Recreational patterns of tourists visiting Europe accessed 27.05.2019. http://www.tourism.government.bg/bg/kategorii/prouchvaniya-i-analizi/prouchvaniya-i-analizi-za-turizma-v-bulgariya-za-2014-g

Ministry of tourism in Bulgaria. Statistics. Accessed 27.05.2019 http://www.tourism.government.bg/bg/kategorii/ statisticheski-danni

Municipal Development Plan of Troyan Municipality for the period 2014-2020. Accessed 27.05.2019: https://www. troyan.bg/attachments/article/895/OPR_Troyan_2014_2020_15.10.2013.pdf Minicipality of Troyan. News section. Assecced 27.05.209 http://www.troyan. $\bar{b} g /$ news/news1/3024-obshtina-troyan-predstavi-proektat-za-sostraprof-hristov-go-opredelya-kato-vizata-za-badeshteto-na-arhitekturniya-kompleks-sostra.html

The Travel \& Tourism Competitiveness Index 2015: http://reports.weforum.org/travel-and-tourism-competitivenessreport- 2015

Updated National Strategy for the Sustainable Development of Tourism in Bulgaria 2014-2030, Decision № 65 from 2nd of February, 2018, Council of Ministers, accessed 27.05.2019 http:/www.tourism.government.bg/bg/kategorii/ strategicheski-dokumenti

\title{
SENOSIOS ROMOS ITVIRTINIMAI - KULTŨRINIS IR ISTORINIS TURIZMO ŠALTINIS
}

\author{
Plamen Lakov, Ivanka Shopova \\ Žemės ūkio ir regioninès pletros universitetas (Bulgarija)
}

\section{Santrauka}

Šis straipsnis - tai mokslinių tyrimų serijos apie senosios Romos vietas Šiaurès Bulgarijoje dalis. Straipsnio tikslas - sudaryti specializuoto kultūrinio-istorinio paveldo turizmo lankomumo sukūrimo galimybes, tai užtikrintų tvarų Bulgarijos materialiojo paveldo panaudojimą. Atliktas Romos įtvirtinimų Sostra kaimelyje Via Traiani kelyje kultūrinio ir istorinio turizmo šaltinio tyrimas. İtvirtinimai apibūdinami kaip kultūros paveldo objektas Trojano (bulg. Троян, angl. Troyan) savivaldybės regione, Bulgarijoje. Siekiant ịvertinti senosios Romos tvirtovès Sostra kaimelyje galimybes taikoma istorinių ir kultūros vietų apibūdinimo metodika. Vertinimas atliktas pagal šiuos kriterijus: plètros galimybès, poveikio / sąveikos laipsnis, modifikavimo laipsnis, taikant tvarumo rodiklius.

Taikytas ir lauko ekspedicijos metodas reljefo tyrimams. Nustatyta, kad iš šioje teritorijoje esančios savivaldybės galima pasimokyti gerosios praktikos, kaip Sostrą kaimeli paversti patrauklia turistų lankoma vieta. Visų pirma savivaldybe šį objektą ịsigijo kaip nuosavybę. Bendradarbiaudama su valstybe ir viešuoju bei privačiuoju sektoriais savivaldybe investavo lěšas ị teritorijos tyrinėjimą, jos išsaugojimą ir atkūrimą. Trojano savivaldybės 2014-2020 m. planavimo dokumentuose darni turizmo plètra laikoma vienu iš penkių regiono plètros prioritetų. Išvados pabrèžia galimybę suformuoti patrauklų kultūrinio ir pažintinio turizmo produktą. Tyrimu nustatyta, kad šio objekto galimybės pritraukti turistus - didžiulès.

PAGRINDINIAI ŽODŽIAI: turistinis išteklius, kultūros turizmas, turizmo politika, regioninị plètra.

JEL KLASIFIKACIJA: L83, R 58.

Received: 2019-09-10

Revised: 2019-09-28

Accepted: 2019-10-01 